\title{
PERSEPSI SENIMAN KRIYA YOGYAKARTA TERHADAP KARYA MEBEL GAYA VINTAGE (Studi Kasus: Jakarta Vintage)
}

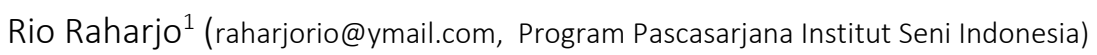

\begin{abstract}
ABSTRAK
Persepsi merupakan istilah yang erat kaitannya dengan psikologi dan neurologi, yang pada hakikatnya mencoba untuk mengetahui penerimaan informasi melalui otak dan memahami bentuk dan makna pada apa yang diinderai, salah satunya karya seni. Namun, dalam pendekatan sosiologi, pemahaman seseorang terhadap bentuk dan makna tersebut, dapat dibentuk melalui pembatinan atas nilai-nilai sosial-budaya di mana seseorang itu berasal (habitus). Untuk dapat mengetahui apa makna dan bagaimana makna tersebut dapat muncul dari para reseptor, yang dalam kasus ini karya mebel dari Jakarta Vintage, menggunakan metode kritik seni. Karya Jakarta vintage yang hadir dengan konsep nostalgia dianggap sebagai pembeda di antara konsep-konsep pada arus utama. Sebagai temuannya, para seniman kriya memahami bahwa makna yang muncul pada tidaklah murni sebagai makna yang utuh.
\end{abstract}

Kata Kunci: Persepsi, Mebel, Jakarta Vintage, habitus

\begin{abstract}
ABSTRACK
Perception is a term close to relation with psychology and neurology, which in naturally try to acceptance know information through the brain and understanding form and meaning what on sensed, one of them is art. But, In the sociology approachment, someone understanding of the forms and meanings, can be formed through pembatinan on social values and culture where someone is coming (habitus). To be able to know what is of meaning and how that meaning can arise from the receptor, which in this case works from Jakarta Vintage furniture, using the method of art criticism. The work Jakarta vintage that comes with the concept of nostalgia is considered as a differentiator between the concepts in the mainstream. As findings, craft artists understand that the meaning appears on it is not pure as meaning intact.
\end{abstract}

Key Word: Perception, Furniture, Jakarta Vintage, habitus

\section{PENDAHULUAN}

Karya seni merupakan benda atau objek yang dapat dilihat, didengar, diraba ataupun dilihat sekaligus didengar. seni itu sendiri sebenarnya sesuatu yang berada di luar benda atau karya itu sendiri sebab seni berupa nilai. Keindahan, humanis, kesederhanaan, dll adalah yang disebut sebuah nilai. Nilai itu lahir dari subjektifitas seseorang karena didasari oleh pengalaman dan pengetahuannya.

(Sumardjo, 45: 2000).

Salah satu yang proses yang membentuk nilai tersebut adalah persepsi. Persepsi merupakan bentuk respon maupun tanggapan 
yang muncul pertama kali dari seseorang atas apa yang diinderainya atau yang dialami secara empirik seperti misalnya sebuah kejadian/peristiwa, benda, gambar dan suara. Persepsi tidak hanya dipengaruhi oleh kesadaran kognitif atau aspek psikologi, namun dapat pula dipengaruhi melalui aspek sosial, seperti lingkungan, kelas sosial dan latar pendidikan dari seseorang tersebut. Artinya, persepsi selalu melibatkan manusia dan menjalin hubungan yang erat karena dihasilkan melalui penginderaan. Apapun yang dapat terinderai selalu memunculkan persepsi, seperti karya seni, khususnya seni kriya bentuk mebel.

Mebel merupakan salah satu produk fungsional yang dirancang untuk memenuhi dan menunjang segala kegiatan yang berhubungan dengan manusia. Mulai dari kegiatan di rumah, bekerja di kantor, belajar mengajar di sekolah hingga kegiatan di ruang publik (Jamaludin, 14: 2007). Keberadaan mebel mulai diminati seiring laju perkembangan arus modernisasi pada suatu wilayah, salah satunya ditandai dengan pembangunan infrastruktur secara signifikan pada kawasan hunian komersil. Adanya pembangunan tersebut, maka kebutuhan akan perabotan/furniture fungsional pun semakin ikut terus meningkat.

Perkembangan beberapa karya mebel dari waktu ke waktu terus mengalami kemajuan berarti, seiring kemajuan teknologi pendukungnya. Masing-masing karya mebel hadir dengan menawarkan berbagai konsep kebaruan dan keunggulannya. Seperti halnya konsep kebaruan atau eksplorasi material, rekayasa mekanis, hingga mengangkat kembali unsur sosial-budaya yang mengandung nilai tradisi atau kembali gaya masa lalu adalah beberapa alternatif konsep dari para desainer.

Konsep bermain dengan masa lalu menjadi salah satu konsep yang melatarbelakangi lahirnya karya Jakarta
Vintage. Konsep masa lalu ini kini digemari pada seni hari ini. Era kontemporer yang cenderung bermain ke masa lalu dirasa menjadi konsep pembeda. Namun konsep tersebut yang tidak lagi mengacu pada makna-makna, tetapi sebuah kegairahan permainan dalam makna (Piliang, 2010: 43). Kehadiran mebel vintage mulai banyak hadir kepermukaan dalam perkembangan desain mebel hari ini. Tetapi jika suatu nilai menjadi populer dan tren dari kebudayaan, maka nilai itu dirasa telah gagal dan tidak sesuai dengan penampilannya (Hamilton, 2012). Artinya, jika segala sesuatunya menjadi tren dari suatu kebudayaan, maka fungsi utama dari nilai tersebut gagal untuk direpresentasikan. Mebel vintage sebagai karya produk yang mengandung nilai historis ditampilkan kembali dan dikemas secara baik, menyesuaikan dengan era masa kini dan dipopulerkan kembali oleh para desainer-desainer tanah air.

Fenomena ini menjadi menarik untuk diamati, kemunculan mebel vintage pada saat ini menjadi warna tersendiri dalam perkembangan desain mebel. Dari kreatifitas mereka, lahir bentuk-bentuk kreasi baru yang menunjukan keterkaitannya dengan nilai kekinian. Berawal dari kegemaran mengoleksi benda antik, Jakarta Vintage berhasil berubah menjadi suatu wadah kreatifitas yang melahirkan gagasan dan konsep nostalgia dengan karya-karya bergaya vintage.

Berdasarkan penjelasan di atas, penelitian ini mengkaji apa makna dan bagaimana makna itu dapat munculpada karya tersebut serta bagaimana seniman kriya memaknaikarya tersebut, dengan studi kasus pada beberapa karya dari Jakarta Vintage. Jika pada penelitian-penelitian sebelumnya yang berkenaan dengan persepsi selalu berkaitan dengan aspek psikologi dan neurologi, maka dalam penelitian ini mencoba melihat melalui perspektif sosiologi yang dirasa menjadi kekosongan dalam pustaka akademik. Sebagai 
asumsi, penelitian ini menganggap dapat dimaknai sebagai pengetahuan yang khas dan dapat memberikan sumbangan pengetahuan dalam dunia akademis.

\section{METODE}

Dalam penelitian ini, metode yang digunakan adalah penelitian kualitatif dengan studi kasus, yakni menyelidiki secara cermat suatu peristiwa, proses atau sekelompok individu yang terjadi dalam kurun waktu tertentu. Dalam pengumpulan data diawali dengan penentuan sumber utama sebagai data primer yakni para seniman kriya yang berada di Yogyakarta dan kemudian dilanjutkan dengan pencarian data pendukung seperti artikel penelitian terkait berupa jurnal yang didapat melalui database atau pangkal data seperti, Ebsco, Proquest; art and humanities, berdasarkan kata kunci yang berkenaan dengan topik tersebut. Buku-buku yang berkaitan dengan topik tersebut juga menjadi sumber pendukung lainnya dalam penelitian ini. Kemudian dilanjutkan dengan melakukan pengamatan terlibat secara tidak penuh. Pengamatan tersebut bertujuan untuk mengetahui perkembangan kehadiran mebel vintage dengan menghadiri secara langsung acara atau pameran dagang barang vintage, melakukan pengamatan di media cetak seperti majalah, katalog dan website sosial media seperti twitter, instagram serta media online lainnya dengan waktu pengamatan setiap minggunya selama 4 minggu. Jumlah yang diwawancara dalam penelitian ini adalah 5 orang, dengan mewawancarai minimal 5 orang (polkinghome dalam Creswell, 209: 2013) data yang didapat setidaknya sudah terwakili secara minimal. Sedangkan untuk alat yang digunakan dalam wawancara adalah alat perekam digital, alat perekam handphone.

Data lainnya berupa dokumen merupakan data yang tercatat atau tertulis dalam suatu media, baik secara audio, visual maupun cetak. Selain bersifat pribadi, dokumen juga dapat bersifat publik (Creswell, 221: 2015). Pada penelitian ini penulis mengumpulkan data dokumen publik yang diterbitkan narasumber melalui website dan akun sosial media.

Tinjauan pustaka yang dilakukan dalam penelitian ini, untuk mengetahui perkembangan penelitian termutakhir khususnya pada topik persepsi dan menghasilkan kekosongan teori. Beberapa kajian pustaka yang dilakukan sebagai tersebut; Emosi negatif dapat memperkaya pengalaman bagi pengguna dalam menggunakan produk dan dapat terus hidup, serta memberikan pengaruh untuk menciptakan kekayaan emosional tersebut (Fokkinga and Desmet, 2013). Ketidakcocokan kesan yang muncul dari pengguna produk atas kesan yang sebenarnya muncul dan tujuan produk dipengaruhi oleh nilai sosial pada produk, posisi produk serta kualitas bentuknya (Khalaj, J., \& Pedgley, O. 2014). Klasifikasi masyarakat dalam penggunaan produk turut mempengaruhi. adanya kecenderungan dominasi sosial individu kelas atas terhadap produk pameran dagang dirasa kurang cocok dengan konsepsi hukum sosial mereka (Rios dkk, 2015). Rekam jejak label memberikan dampak yang berarti dalam mempengaruhi konsumen untuk menilai sebuah produk (Bradu dkk, 2014).

Produk yang tidak diproduksi secara luas atau masal dirasa lebih memiliki pertanggung jawaban secara sosial (Janssen, dkk. 2013). Produk yang paling indah terletak pada nilai kebaruannya dan bentuk tiga dimensi mendasar yang mempengaruhi penampilan estetis dari suatu produk adalah aspek kekinian, kerumitan dan nilai emosional (Hung, W. K., \& Chen, L. L. 2012). Melalui tiga aspek itulah, seseorang dapat mempersepsi suatu karya. Wujud dari ketiga aspek tersebut dapat terlihat dari bentuk visual dari karya tersebut. 
Persepsi manusia saat melihat produk yang memiliki tekstur dipengaruhi oleh ekspektasi visual, sentuhan langsung dan keduanya (Yanagisawa, Takatsuji. 2015). Persepsi pengunjung dipengaruhi oleh kenyamanan bentuk yang tematik, mudah dibaca, memiliki citra sosial dan interaksi serta dekorasi (Kusumowindagdo, Astrid \& Sachari, Agus. 2015). Kemudian, Brand global juga turut mempengaruhi persepsi seseorang dalam menilai seuatu produk lebih trendy dan lebih estetis (Blijlevens, J., Mugge, R., Ye, P., \& Schoormans, J. P. L. 2013). Persepsi manusia yang paling jujur dipengaruhi oleh elemen situasi masing-masing individu secara empiris (Reibeiro, 2014).

Berdasarkan penelusuran penelitian terkait, persepsi seseorang terhadap produk secara menyeluruh banyak menaruh perhatian pada aspek psikologi, tampilan visual, strata sosial, nilai sosial namun belum ada yang menunjukan kajian persepsi terhadap karya seni atau produk melalui pendekatan ilmu sosiologi dengan melibatkan pelaku seni.

\section{Temuan dan Pembahasan}

\section{Mempersepsi dengan Sosiologi}

Persepsi merupakan istilah untuk menjelaskan aplikasi dari penelitian neurologi dan penerimaan secara prinsip psikologi dalam sebuah studi komunikasi visual. Dengan tujuan untuk mengetahui, bagaimana otak menerima informasi itu, memproses itu, mendapatkan maksud dari bentuk itu (Barry, 2005: 45). Tentunya informasi tersebut dengan melibatkan pembacaan atas teks yang awal kemunculannya selalu mendapat tanggapan dari pembacanya. Teks di sini tidak diartikan sebagai teks yang tertulis saja, namun teks dapat berupa wujud, purwarupa yang dapat diinderai. Artinya, resepsi memiliki keterkaitan terhadap pemahaman suatu bentuk dan makna pada karya seni yang melibatkan para reseptor.
Hal ini juga serupa dengan beberapa pendekatan dalam ilmu semiotika yang salah satunya, pembacaan makna karya seni dengan melibatkan audiens atau tanggapan dari si pembaca. Dalam pendekatan ini, menekankan atas pengalaman si pembaca itu sendiri yang terlepas dari ikatan. Pembacaan tersebut ditentukan oleh pengetahuan terhadap karya seni, pekerjaan, tempat tinggal, pendidikan dan agama atau yang biasa disebut horizon harapan Jauss (1983: 24). Dalam konteks ini, reseptor melibatkan seniman yang bergelut di bidang seni kriya.

Masyarakat adalah sekumpulan manusia yang saling "bergaul" atau saling berinteraksi. Koentjaraningrat menambahkan masyarakat adalah kesatuan hidup manusia yang berinteraksi menurut suatu sistem adat-istiadat tertentu, dan yang terikat oleh suatu rasa identitas bersama (Koentjaraningrat, 2009: $116,118)$. Masyarakat seniman kriya di Jawa yang tumbuh dan berkembang sejak abad ke-9 pada masa Dinasti Shailendra dan Sanjaya, telah lama memiliki sebuah pandangan secara ontologis dalam proses penciptaan karya seni. Pandangan ini kemudian semakin berkembang secara perlahan ke dalam bentuk seni bangunan dan ornamentasinya pada tempat peribadatan seperti candi. Pandangan ini terus memberi pengaruhnya dan diartikulasikan secara baik hingga masuknya agama Islam di Kerajaan Mataram Islam hingga Keraton Ngayogyakarta Hadinigrat. Karya seni baik bangunan dan ragam hiasnya maupun perabot yang dihasilkan tidak hanya berbicara masalah keindahan, namun juga mengandung nilai makna. Ini menunjukan bahwa, pandangan ontologis masih digunakan sebagai ide penciptaan oleh para kriyawan di tanah Jawa khususnya Yogyakarta. Dari tangan-tangan terampil kriyawan tersebut lahirlah sebuah karya yang syarat makna (form follow meaning). Dengan pandangan tersebut, seniman kriya di Yogyakarta dirasa juga dapat 
mempersepsi sebuah karya seni lainnya berdasarkan perspektifnya, alam konteks ini pada seni kriya mebel.

Pemahaman seni tidak hanya berdasarkan bakat alamiah yang tersebar secara universal dimiliki oleh semua orang, karena pemahaman tersebut melibatkan lebih banyak hal daripada sekedar pemahaman langsung dan serta merta terhadap karya. Namun, tanpa disadari, prinsip-prinsip universal tersebut dapat menstrukturkan secara personal atas pemahaman tersebut. Dalam hal ini yakni sistem pendidikan cenderung menciptakan sebuah arah penempatan budaya yang secara bertahap dilekatkan pada status sosial tertentu. Serta memungkinkan sistem pendidikan dan selera dapat disusun menjadi suatu susunan yang berarti (Bourdieu, xivi: 2010). Artinya, kondisi sosial memiliki peran dalam mengkonstruksi persepsi-persepsi individual. Bahkan dapat memegang peranan dalam menstrukturkan pengalaman/tindakan secara personal.

Maka, pandangan praktis Marxis yang menyatakan faktor ekonomi sebagai basis yang turut menentukan faktor-faktor lainnya dirasa kurang tepat. Artinya, sebuah persepsi seseorang tidak lagi ditentukan oleh faktor ekonomi, melainkan oleh kondisi sosial yang membentuk perkembangan masyarakat tersebut. Kondisi sosial begitu dominan dengan mengesampingkan peran subjek, kini telah berubah dengan melibatkan peran subjek/agen. Dan agen sosial bukan lah seperti mesin seperti jam, tetapi dalam praktiknya relasi sosial atau individu-individu menjalankan suatu prinsip-prinsip sosial-budaya yang kemudian terbantinkan yang akan membuat orang bertindak sesuai dengan aturan itu dan menjadi habitus (Bourdieu dalam Lubis, 112: 2014). Habitus merupakan sebuah proses pembentukan watak seseorang berdasarkan kondisi sosial tertentu. Habitus dapat mempengaruhi sebuah selera seseorang melalui proses kebatinan yang didapatkan dalam sebuah lingkungan.Lingkungan yang menjadi peran sentral dalam membentuk seseorang, turut pula mempengaruhi dalam proses terciptanya karya seni, di mana seni merupakan hasil dari aktivitas manusia yang dilahirkan melalui tahapan konseptual dalam sebuah entitas masyarakat.

\section{Mengenali Mebel Sebagai Sebuah Teks}

Dewasa ini seiring perkembangan dan pemapatan waktu, mebel terus mengalami perkembangan yang berarti. Pengertian mebel secara umum adalah benda pakai yang dapat dipindahkan, berguna bagi kegiatan hidup manusia, mulai dari duduk, tidur, bekerja, makan, bermain dan sebagainya, yang memberi kenyamanan dan keindahan (Bayley dalam Walker, 2010:26) bagi para pemakainya. Konsep tersebut lebih cenderung didominasi oleh gaya modern yang dirasa sudah menjadi arus utama dalam konteks kekinian, sehingga memaksa untuk melahirkan suatu yang berbeda.

Era kontemporer sekarang ini, apapun dapat saja dilakukan dengan mengatasnamakan seni (anything goes). Konsepsi pembeda dari arus utama dalam kasus ini, karya-karya Jakarta Vintage yang hadir dengan konsep nostalgia. Jakarta Vintage awalnya hadir sebagai akun pribadi yang dibuat sekitar tahun 2013-an dengan menggunakan media jaringan internet ini yang berisikan tentang catatan pribadi terhadap benda-benda antik dalam bentuk narasi. Benda-benda tersebut berupa produk yang memiliki nilai historis seperti jam, koper, piringan hitam, turntable, chronograph, aksesoris ruangan dan khususnya adalah furniture/mebel. Tujuan dari konsep tersebut adalah mencoba mengajak penggunanya untuk mengingat kembali kenangan atau memori masa lalu.

Berdasarkan dari gagasan tersebut, maka turut pula mempengaruhi pola berpikir kreatif dan 
inovatif dalam proses perwujudan setiap karyanya. Karya-karya mebel dari Jakarta Vintage ini cenderung menerapkan konsep remake-over, restored and refinished dalam setiap karyanya, yakni dengan sedikit mengubah tampilan awal menjadi tampilan yang baru dan unik. Agar tetap mengandung nilai historis, karya-karya tersebut diperbaiki ulang, difinishing kembali seperti tampilan awalnya.

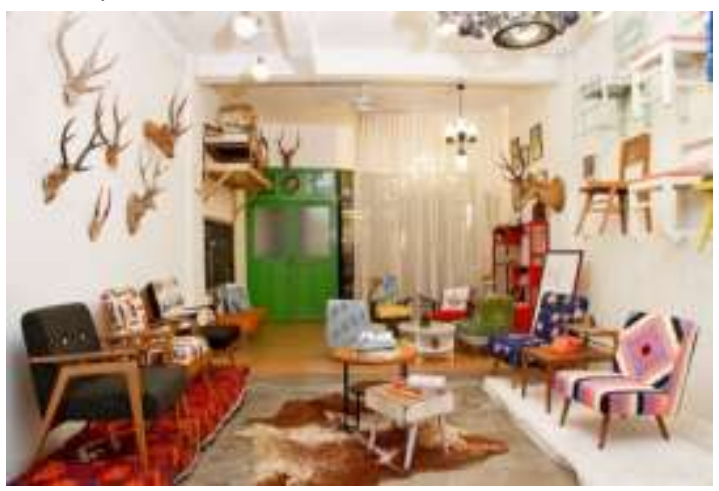

Gambar 1. Showroom Jakarta Vintage

Sumber:

https://gustosign.files.wordpress.com/2014/11/jakartavintage.jpg

Mebel, dalam penggunaanya di masyarakat selain sebagai sarana pemenuhan kebutuhan hidup, yang memang merupakan bagian dari fungsi praktisnya, juga merupakan bagian dari aspek estetis dan ideologis. Aspek estetis yang berhubungan dengan gaya juga berkaitan dengan ekspresi atau pesan dari desainernya yang disampaikan melalui karyanya. Setiap bentuk dan gaya pada suatu karya memiliki makna sesuai dengan ideologi visualnya.

Pesan dan makna suatu karya dapat diketahui jika melalui tahapan-tahapan dalam kritik seni, yakni dengan mendeskripsikannya terlebih dahulu. Istilah kata deskriptif dalam sebuah karya seni berfungsi sebagai penunjuk yang mengarahkan pembaca kepada sesuatu yang layak untuk diperhatikan.

Pengenalan terhadap unsur-unsur rupa pada sebuah karya seni atau desain akan membantu dalam mendeskripsikan karya tersebut. unsur-unsur itu meliputi, garis, bidang, arah, ukuran sehingga membentuk sebuah karya atau desain (Sanyoto, 2010: 83-126)

Penjelasan deskripsi dari salah satu karya Jakarta Vintage adalah sebagai berikut:

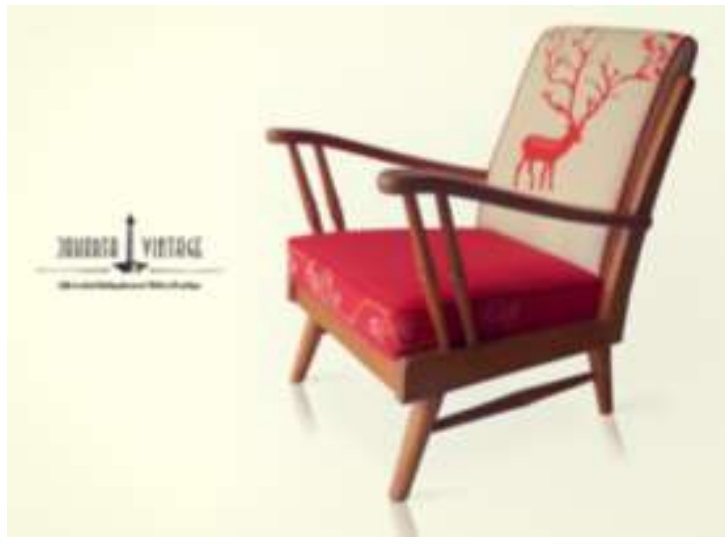

Gambar 2. Karya MebelJakarta Vintage

Sumber: http://jakartavintage.co/2013/10/22/octoberarrival-new-jakarta-vintage-chair-collection/

Judul: Red Deer Media: Kayu Jati Tua Tahun: 2013 Material: Kanvas Cetak, Kayu Jati Tua. Ulasan/Kritik Karya: Desainer menggunakan konsep remake-over atau mengolah kembali barang lama dan kemudian mengubahnya dengan tampilan baru, tetapi tetap memiliki fungsi yang sama. Mebel ini bertemakan fun ceria dengan penggunaan warna merahterlihat dominan pada jok menjadi bantalan dudukan dan motif fauna pada jok sandaran. Sedikit patron motif floral yang menghias mengeliling pada bantalan dudukan kursi ini. Karya kursi ini dibentuk dengan perpaduan garis lengkung dan statis yang saling bertemu pada setiap ujung bidangnya. Garis-garis yang menjadi elemen subjek matter dihasilkan dari proses pembentukan kursi dengan menggunakan teknik secara masinal. Pertemuan garis tersebut yang menghasilkan secara keseluruhan bentuk dari kursi tersebut. lebih spesifik lagi, garis lengkung lima dari pandangan sebelah kiri membentuk armrest/ sandaran tangan dan garis lengkung busur membentuk back splat/sandaran belakang 
Tekstur nyata yang bersifat halus terdapat pada setiap permukaan karya, baik pada seluruh bagian komponen terluar kursi maupun pada masing-masing jok.

Selain itu, untuk dapat mengetahui mengapa karya itu terbentuk, pendekatan formalistik digunakan mengetahui bagaimana unsur-unsur rupa diorganisir dalam suatu area atau medium sehingga membentuk karya seni. Selain itu dalam analisis ini, tidak menyinggung secara detail tentang teknik dalam karyanya, tetapi mendeskripsikan kualitas garis, bentuk, warna dan pencahayaan yang merupakan hal pertanggung jawaban atas terbentuknya karya tersebut, materi subjek (Fieldman, 1967: 473).

Seluruh bidang dari karya ini didominasi dengan garis tipis lengkung yang terbentuk karena ingin memberikan karakter ringan dan kedinamisan. Bentuk organis dibuat berdekatan guna membangun kesan menyatu. Repetisi garis berjajar secara vertikal pada arm support memunculkan kesan kuat dan rapi. Gaya abad pertengahan modern ini memberikan kesan kenangan masa lalu yang dikombinasikan dengan tema alam pada motif floral dan fauna atau biasa disebut dengan eklektik. Pada bagian stile/tumpuan sandaran masih kokoh dengan penggunaan kayu solid dengan garis melengkung lembut, sama halnya pada armrest atau sandaran tangan yang juga dibentuk mengikuti garis landai tentunya dengan tambahan arm support/ sebagai penopang sandaran tangan. Arm support yang dibentuk dengan teknik bubut masinal sedikit memberi kesan kolonial dengan garis membesar di tengah kemudian mengecil ke arah yang berlawanan.

Bentuk yang sederhana, natural tanpa ukiran yang juga masih mendapat pengaruh dari gaya modern atau Bauhaus tahun 1920an pasca perang dunia ke 2. Garis-garis halus, bersih dan pemahaman terhadap bahan serta proporsi bentuk tubuh manusia menjadi andalan pada gaya ini. Mengadopsi teknik produksi massal dan menitikberatkan pada bentuk dan fungsi. Dalam kaki-kaki kursi, sandaran tangan dan konstruksinyamisalnyamenjadimengecil atau menyempit searah dengan teknik bubut, daripada gaya modern yang sebelumnya cenderung tegak lurus dan menjadi kekhasan dari periode ini.

\section{Antara Penanda dan Petanda}

Teori tentang tanda secara populer telah digunakan oleh ahli pemikir di-Jerman pada abad ke -18 sebagai suatu susunan kata yang berasal dari logika. Teori ini selanjutnya dikembangkan oleh dua orang tokoh yang menjadi penggagas awal tentangsemiotika dalam bidang linguistik yaitu Charles Sanders Pierce dan Ferdinand de Saussure. Menurut Pierce, logikalah yang mempelajari bagaimana orang berabstraksi, berpikir, berkomunikasi, dan memberi makna terhadap apa yang ditampilkan oleh alam kepada orang lain melalui sebuah tanda. Dan lagi menurutnya, pemaknaan terhadap tanda bisa berarti sangat luas baik dalam bidang linguistik maupun tanda-tanda lainnya yang bersifat umum (Sachari, 2005: 62).

Pemikiran Peirce kemudian dikembangkan oleh Umberto Eco di Eropa dan sekaligus mencoba kemungkinan bahwa pemikiran tersebut dapat diaplikasikan pada kajian bidang arsitektur, visual, teater, dan seterusnya. Semiotika tidakhanya berfungsi sebagai ilmu tanda saja, namun mengkaji bagaimana sebuah tandaitu berfungsi serta hubungannya dengan tandalainnya hingga berlanjut pada proses pengiriman dan penerimaan oleh penggunanya. Analisis mengenai fungsi tanda dikenal dengan istilah sintaks-semiotik. Kemudian analisis yang berhubungan dengan penafsiran tanda dikenal dengan istilah semantik-semiotik, sedangkan analisis tanda yang hubungannya dengan pengirimnya dikenal sebagai semiotik- 
pragmatik. Dan bagi Pierce tanda bermakna 'mengemukakan sesuatu'(representatemen) (Sachari, 2005: 62).

Kemudian seorang Ferdinand de Saussure yang menggagas metodologi semiotika memposisikan tanda dalam sebuah konteks komunikasi manusia dengan melakukan seleksi antara apa yang disebut signifier (penanda) dan signified (petanda). Signifier adalah bunyi atau teks yang bermakna (aspek material), yakni apa yang diinderai oleh seseorang. Signified adalah konsep mental, yakni pikiran atau konsep abstrak terhadap sebuah teks. Kedua unsur tersebut layaknya dua sisi dari sekeping mata uang yang saling berkaitan. Dan hubungan antara keberadaan aspek material dan konsep mental selanjutnya dinamakan signification.Dengan kata lain, signification adalah upaya untuk memberi makna terhadap dunia (Sobur, 2009: 125). Hubungan komunikasi yang terjalin antara manusia dengan sebuah objek merupakan pertukaran makna yang terjadi secara dua arah. Makna mendapat diartikan sebagai apa yang telah diinderai dan banyak hal yang bisa diungkap atas apa yang terkandung didalamnya. Namun dapat pula makna itu bertahan secara temporal karena pengaruh konvensi kuno, artinya manusia tidak dapat memberi makna baru atas apa yang telah diinderai.

Jika berpijak pada hasil deskripsi atas karya tersebut, tindakan ini merupakan salah satu upaya untuk mengidentifikasi penanda/signifier yang membentuk suatu tanda, guna mengidentifikasi pula petanda/signified atau konsep apa yang terbentuk. (Marianto, 2015: 95). Artinya, hasil dari mendeskripsikan itu mempermudah untuk mengetahui mana yang disebut sebagai penanda dan petanda pada karya tersebut.

Pada salah satu karya Mebel Jakarta Vintage yang berjudul Red Deer, memberikan penjelasan bahwa adanya petanda/makna yang diletakan pada teks tersebut adalah sebagai sebuah konsep/ide. Sebagai sebuah penanda/signifier, wujud atau objek material. Dalam konteks ini, kursi yang membentuk sebuah tanda. Tanda sebagai (repsentament) di sini diberi makna oleh intepretant melalui identifikasi teks, seperti garis yang melengkung, bentuk yang organis, modifikasi pada material jok dengan motif hewan dan floral, serta warna mencolok memberikan kesan ceria dan kekinian. Dari sinilah upaya untuk memaknai karya tersebut terbangun (signification). Intepretasi atas tanda, dihasilkan oleh penanda itu sendiri sehingga tanda tersebut dapat dimaknai dan memantikan sebuah kesan.

\section{Penilaian Atas Konsep Nostalgia}

Istilah art conservation memiliki makna denotasi perawatan pada sebuah karya seni dan untuk melindungi dari kerusakan nantinya. art restoration juga memiliki makna denotasi yakni memperbaiki atau merenovasi karya seni yang sudah mengalami kerusakan (Britannica Encyclopedia). Istilah ini berkaitan dengan bentuk perlindungan terhadap karya seni yang pada umumnya dilakukan oleh pihak museum karena museum merupakan tempat yang mengoleksi dan menyimpan benda bersejarah.

Jika perpijak dari penyataan tersebut, esensi dari pemeliharaan dan perbaikan kembali pada karya seni tersebut adalah murni untuk kepentingan melestarikan. Pada umumnya tindakan ini dapat dijumpai di museum-museum besar yang memiliki nilai sejarah peradaban yang tinggi karena memang untuk kepentingan melestarikan karya-karya yang bernilai historis. 


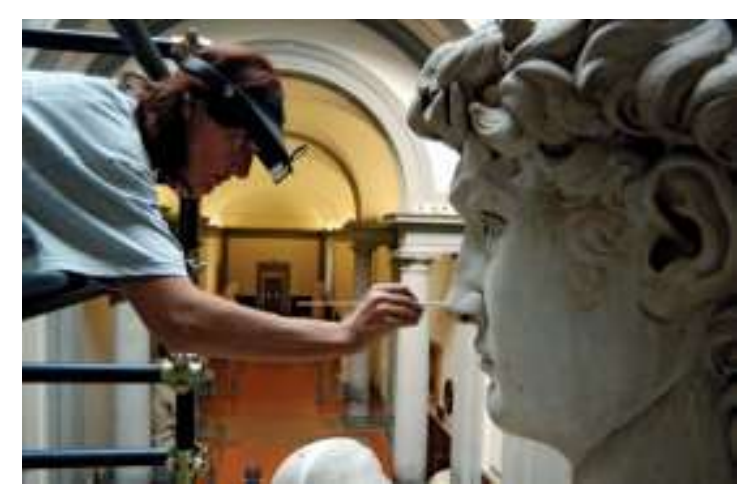

Gambar 3. Proses restorasipada karya

Michelangelo's David, 2002.

http://media-2.web.britannica.com

Restorasi karya seni umumnya dilakukan pada jenis karya seni rupa, seperti lukisan, patung, dll. Namun dalam perkembangannya, proses restorasi ini kemudian merambah dalam bidang seni terapan lainnya seperti furniture/mebel. Dalam ranah restorasi, furniture/mebel termasuk dalam kategori seni dekoratif, di mana memiliki tujuan yang sama, yakni memelihara dan memperbaiki kembali demi kepentingan melestarikan karya mebel tersebut. Karya-karya mebel yang dihasilkan pada saat itu masih menggunakan teknik manual atau dengan keahlian dan keterampilan tinggi serta penggunaan bahan seperti sambungan pun masih menggunakan bahan alami, seperti bahan perekat, dan konstruksi pasak.

Karya Jakarta Vintage hadir di tengah animo masyarakat kontemporer yang menginginkan konsep-konsep baru lahir sebagai salah satu alternatif pilihan. Ketika menginginkan sebuah konsep yang berbeda dalam masyarakat yang homogen, masyarakat kontemporer mencoba memaknai ulang pada setiap karya yang digubahnya. Selain itu kecenderung melihat dan bermain ke masa lalu dengan memunculkan bentuk dan gaya-gaya masa lalu agar dianggap sesuatu yang berbeda, hal ini lah yang mendasari mengapa konsep tersebut lahir.

Jika melihat pada sejarah restorasi dan konservasi karya seni, murni dilakukan untuk kepentingan menjaga kerusakan dan memperbaiki ulang karya tersebut, tanpa mengubah tampilan visualnya. Maka dalam konteks ini, konsep restorasi yang diterapkan pada karya Red Deer, bertolak belakang dengan esensi restorasi tersebut. Hal ini dikarenakan, terdapat perubahan pada beberapa material dan tampilan visual sehingga makna awal yang sudah melekat pada karya tersebut ikut berubah.

Para seniman kriya Yogyakarta maknai bahwa konsep nostalgia yang digagas, menghadirkan kesan banalitas, tanpa ada pendalaman secara khusus karena tidak adanya sebuah makna simbolik yang utuh. Selain itu, reseptor memaknai bahwa karya tersebut tidak murni mengandung nilai historis, karena terdapat beberapa perubahan secara signifikan. Seniman kriya memahaminya sebagai karya yang memiliki kepentingan ekonomis.

\section{PENUTUP}

Persepsi yang pada umumnya berkenaan dengan sifat praktik neurologi dan psikologi, memiliki tujuan yang sama dengan resepsi, yakni mengetahui bagaimana otak menerima informasi itu hingga memahami makna dan bentuk pada sebuah karya seni. Pemahaman tersebut juga dipengaruhi oleh lingkungan, tempat tinggal dan pendidikan secara batiniah.

Mebel vintage hadir menyesuaikan dengan jiwa jamannya, kekinian dan lahir dari masyarakat kontemporer yang menginginkan sebuah konsepsi berbeda dari yang telah ada. konsep mencoba bermain untuk kembali ke masa lalu hingga mengadaptasi gaya-gaya dan bentuk masa lalu dirasa menjadi konsep utama dalam menghasilkan sebuah karya. Jakarta Vintage mencoba hadir dengan karya-karya lama, karya-karya yang dapat menggugah ingatan, kenangan dan nostalgia kehidupan masa lalu dengan cara merestorasi, refinishing dan remake-over karya tersebut. 
Namun, konsep tersebut memiliki tendensi untuk kepentingan pasar, karena pada dasarnya, restorasi dan konservasi pada karya seni hanya untuk kepentingan memperbaiki ulang, merawat serta menjaga dari kerusakan. Restorasi pada umumnya masih tetap menjaga keaslian bentuk visual pada setiap karyanya, seperti mengganti bagian-bagian sambungan atau memperbaiki ulang komponen-komponen tertentu tanpa ada perubahan sedikitpun apalagi memodifikasi. Jika hal tersebut dilakukan maka makna yang telah diletakan pada karya tersebut jelas ikut berubah. Maka, pentingnya untuk menjaga keaslian dari tampilan visual tersebut.

Perubahan makna pada sebuah karya dapat dipengaruhi oleh penanda/objek itu sendiri yang kemudian diintepretasikan sehingga menghasilkan sebuah makna baru dan menjadikannya sebuah tanda (representament). Para seniman kriya mempersepsi bahwa tanda pada karya yang berjudul Red Deer, dimaknai sebagai karya yang tidak murni mengandung nilai historis karena sudah mengalami perubahan yang signifikan.

Mebel vintage merupakan karya desainer mebel yang lahir di era kekinian dengan mengadopsi bentuk-bentuk lama, dikemas dengan tampilan masa kini. Perkembangan mebel masa kini turut mewarnai perkembangan mebel dari waktu ke waktu. Namun, jika konsep yang digagas hanyalah murni atas kepentingan ekonomi, maka makna tersebut kemungkinan tidak akan tersampaikan atau terbaca dengan baik. Terkesan bermain-main.

Pada penerepannya, konsep selalu berbanding lurus dengan proses perwujudan karyanya agar pesan dapat tersampaikan secara baik. Untuk itu, jika ingin mengusung konsep masa lalu, hendaknya karya yang ditampilkan pun turut mengandung makna yang asli, murni agar pesan dari karya juga berkesan murni dan utuh.

\section{Daftar Pustaka}

Barry, Ann Marie. 2005. Hand Book of Visual Communication: Theory, Methods and Media. New Jersey: Lawrence Erlbium Associates. Inc

Blijlevens, J., Mugge, R., Ye, P., \& Schoormans, J. P. L .2013. The Infuence of Product Exposure on Trendiness and Aesthetic Appraisal. International Journal of Design, 7(1), 55-67.

Bradu, Cosmina, dkk. 2014. The Mediated Influence of a Traceability Label on Consumer's Willingness to Buy the Labelled Product. J Bus Ethics, 124:283295

Bourdieu, Pierre. 2010. The Field of Cultural Production: Essay on Art and Literature (terj. Yudi Santosa). Yogyakarta: Kreasi Wacana.

Creswell, John. 2015. Penelitian Kualitatif \& Desain Riset ed. 3. Yogyakarta: Pustaka Pelajar.

Fieldman, Edmund Burke. 1967. Art as Image and Idea. New Jersey, Englewood: PRENTICE HALL. INC

Fokkinga, S. F., \& Desmet, P. M. A. (2013). Ten Ways To Design For Disgust, Sadness, And Other Enjoyments: A Design Approach To Enrich Product Experiences With Negative Emotions. International Journal of Design,7(1), 19-36s

Hung, W. K., \& Chen, L. L. 2012. Effects of Novelty And Its Dimensions on Aesthetic Preference In Product Design. International Journal of Design, 6(2), 8190.

Hamilton, Caroline. 2012. Seeing the World Second Hand; Mad Men and the Vintage Consumer. Cultural Studies Review 22341.

Jamaludin. 2007. Pengantar Desain Mebel, Bandung: Kiblat Buku Utama. 
Janssen, Catherine dkk. 2014. The Catch-22 of Responsible Luxury: Effects of Luxury Product Characteristics on Consumers' Perception of Fit with Corporate Social Responsibility. J Bus Ethics 119:45-57.

Jauss, Hans Robert. 1983. Toward an Aesthetic of Reception. Minneapolis : University Of Minnesota.

John. A. Walker, 2010, Design History and The History Of Design (Terj. Laily Rahmawati), Yogyakarta: Jalasutra.

Khalaj, J., \& Pedgley, O. 2014. Comparison of Semantic Intent And Realization In Product Design: A Study on High-End Furniture Impressions. International Journal of Design, 8(3), 79-96.

Koentjaraningrat, 2009. Pengantar IImu Antropologi. Jakarta: Penerbit PT. Rineka Cipta Press.

Kusumowidagdo, Astrid \& Sachari, Agus. 2015. Visitor Preference Factors toward Shopping Centres Thematic Corridor Study of Gandaria City, Indonesian Shopping Centre. Journal of Arts \& Humanities.

Lubis, Akhyar Yusuf. 2014. Postmodernisme: Teori dan Metode. Jakarta: PT. Rajagrafindo Persada.

Marianto, Dwi. 2015. Art and Levitation Seni dalam Cakrawala. Yogyakarta: Penerbit Pohon Cahaya

Piliang, Yasraf Amir. 2010. Dunia Yang Dilipat; Tamasya Melampaui Batas-batas Kebudayaan, Yogyakarta : Jalasutra

Rios, Kimberly, dkk. 2015. Is There A "Fair" In Fair-Trade? Social Dominance
Orientation Influences Perceptions of And Preferences For Fair-Trade Products. Bus Ethics 130:171-180.

Sachari, Agus. 2005. Pengantar Metodologi Budaya Rupa; Desain, Arsitektur, Seni Rupa dan Kriya. Jakarta: Erlangga.

Sobur, Alex. 2003. Semiotika Komunikasi. Bandung: Remaja Rosdakarya,

Sanyoto, Sadjiman Ebdi. 2010. Nirmana; Elemen-Elemen Seni dan Desain, Yogyakarta: Jalasutra.

Yanagisawa, H., \& Takatsuji, K. 2015. Effects of Visual Expectation on Perceived Tactile Perception: An Evaluation Method of Surface Texture With Expectation Effect. International Journal of Design, 9(1), 39-51.

Britannica.com. Art Conservation and Restoration. April 18, 2016

http://www.britannica.com/art/artconservation-and-restoration/ (accesed Juni 7, 2016) Jakartavintage.co, chairs. April 10, 2016. http://jakartavintage.co/2014/05/18/vintageon-weekends/ (accesed Juni 7, 2016) 